\title{
Health, wealth, and education: the socioeconomic backdrop for marine conservation in the developing world
}

\author{
Brendan Fisher ${ }^{1,2, *, * *}$, Alicia M. Ellis ${ }^{2, * *}$, Diane K. Adams ${ }^{3}$, Helen E. Fox ${ }^{1,5}$, \\ Elizabeth R. Selig ${ }^{4}$ \\ ${ }^{1}$ Conservation Science Program, World Wildlife Fund, 1250 24th Street NW, Washington, DC 20037, USA \\ ${ }^{2}$ Gund Institute for Ecological Economics, Rubenstein School of Environment and Natural Resources, University of Vermont, \\ 617 Main Street, Burlington, VT 05405, USA \\ ${ }^{3}$ Department of Marine and Coastal Sciences, School of Environmental and Biological Sciences, Rutgers University, \\ 71 Dudley Road, New Brunswick, NJ 08901, USA \\ ${ }^{4}$ Betty and Gordon Moore Center for Science and Oceans, Conservation International, 2011 Crystal Drive, Arlington, VA 22202, USA \\ ${ }^{5}$ Present address: RARE, 1310 N. Courthouse Rd., Ste. 110, Arlington, VA 22201, USA
}

\begin{abstract}
Interacting drivers and pressures in many parts of the world are greatly undermining the long-term health and wellbeing of coastal human populations and marine ecosystems. However, we do not yet have a well-formed picture of the nature and extent of the human poverty of coastal communities in these areas. In this paper, we begin to fill the gap and present a multidimensional picture of the wellbeing of coastal communities, using nationally representative survey data to examine the health, wealth, and educational status of households in over $38000 \mathrm{com}$ munities across 38 developing countries. In general, we found high levels of poverty across the 3 dimensions (health, wealth, and education) analyzed, but each dimension also showed large heterogeneity within and across countries. We found that coastal communities had statistically significant higher levels of wellbeing than non-coastal communities. Coastal children were less stunted, less poor, and more likely to live in a higher educated household when compared to non-coastal households. However, we found that across coastal communities, rural coastal communities had 1.5 times lower height-for-age standard deviation scores (representing high childhood stunting rates), were 4 times more likely to be poor, and were 1.6 times more likely to have low levels of educational attainment. A deeper understanding of human wellbeing along coasts is critical for generating wider social and more long-term economic benefits with respect to coastal marine management.
\end{abstract}

KEY WORDS: Coastal marine systems - Human health - Childhood stunting · Poverty Human wellbeing $\cdot$ Education

Resale or republication not permitted without written consent of the publisher

\section{INTRODUCTION}

Multiple drivers and pressures in many parts of the world are greatly undermining the long-term health and wellbeing of coastal human populations and the marine ecosystems they depend on. Cumulative impacts from fishing, climate change, and land-based and ocean-based pollution affect every marine ecosystem across the globe (Halpern et al. 2008). As a result, $87 \%$ of global fish stocks are now fully exploited, overexploited, or depleted (FAO 2012), and critical habitats are at risk (Hughes et al. 2003).

These cumulative impacts on marine ecosystems often affect the delivery of ecosystem services to 
people already suffering from challenging socioecological conditions. For example, in a country-level analysis of the vulnerability of fisheries to climate change impacts, Allison et al. (2009) found that 16 of 31 highly vulnerable countries are among the world's least developed countries (e.g. Senegal, Mozambique, and Gambia). In that analysis, vulnerability was a function of the combined effects of predicted warming, the relative importance of fisheries to national economies and diets, and societal capacity to adapt to potential impacts. Across the developing world, countries that depend on coastal resources are often also plagued with low levels of human capital, high food insecurity, and low capacity for implementing sound management policies (Smith et al. 2010, Fox et al. 2012b, Hughes et al. 2012).

While we are attaining a better understanding of the ecological status of our ocean (Halpern et al. 2008, 2012, FAO 2012), we still do not have a comprehensive picture of the nature and extent of the poverty of coastal communities around the world or the kind of fishing activities occurring, and at times we do not even have an accurate number of those engaged in fishing (Kittinger 2013). Best estimates suggest that some 260 million people are employed in marine fisheries sectors across the globe (Teh \& Sumaila 2013). Of this number, an estimated 22 million are smallscale fishers (Teh \& Sumaila 2013). In addition to the fuzzy statistics around fishing and fishing livelihoods, the complex nature of coastal fisheries and livelihoods often means that clear problem definition and analysis of coastal challenges is difficult to establish (Jentoft \& Chuenpagdee 2009). As such, much of the research on the dimensions of poverty in coastal areas of the developing world has been based on case studies in single countries (e.g. Marschke \& Berkes 2006) or derived from spatially insensitive, nationalscale reporting efforts from organizations such as FAO (2012). The former are limited because they lack the generalizability for policy formation, while the latter are limited because their results cannot reflect poverty at the scale of management interventions. Decision-makers, donors, and non-governmental organizations need information about the status of coastal human populations to better design policy, implement management, and more effectively allocate conservation and development resources. In this paper, we begin to fill the gap left by the case studies and aggregated statistics and present a multi-dimensional picture of the wellbeing of coastal communities across 38 countries around the globe.

We focus on several dimensions of poverty because since the pioneering work of Amartya Sen (e.g. Sen
1985), it has been clear that defining 'development' or 'poverty' simply along an income or wealth axis is inadequate. The Human Development Index (HDI), created and adopted by the United Nations to track national-level development progress, was based in large part on Sen's work. From the initial Human Development Report (UNDP 1990), it was recognized that of all the dimensions of development, the 3 critical ones are 'for people to lead a long and healthy life, to acquire knowledge and to have access to resources for a decent standard of living' (UNDP 1990). Key metrics used to assess these dimensions are (1) life expectancy at birth (for the long and healthy life dimension), (2) adult literacy and school enrollment rates (for acquiring knowledge), and (3) gross domestic product (for standard of living) (Sagar \& Najam 1998).

Using this framing for our multi-dimensional understanding of the wellbeing of coastal communities, we examine analogous health, wealth, and education metrics for households in over 38000 communities across 38 developing countries for which we have nationally representative survey data. To see if there is a difference between coastal communities and noncoastal communities, we first ask how communities within $20 \mathrm{~km}$ of the coast compare to non-coastal communities in health, wealth, and education metrics. These analyses are designed to address the question of whether 'fishery rhymes with poverty' (Béné 2003, p. 949) by comparing the wellbeing of coastal communities with non-coastal communities. We then explore the data to see how rural and urban coastal communities compare in terms of health, wealth, and educational status across these 38 countries. This rural-urban exploration is important given that we would expect differential outcomes between the 2 groups (e.g. Van de Poel et al. 2007). While the share of the world's poor living in urban areas is rising, $75 \%$ of the developing world's poor still live in rural areas (Ravallion et al. 2007). Rural poverty is often typified by 'access poverty,' including lower levels of access to education, markets, and financial services (Jalan \& Ravallion 1999, Ravallion 2001). However, in some cases, rural communities are less vulnerable to poor governance and economic shocks given their geographical and market isolation (Satterthwaite 2002) and natural resource base (Schaafsma et al. 2014). As such, we test to see how rural and urban contexts affect the health, wealth, and educational status of the coastal communities in our dataset.

Although our analyses are descriptive, they are an important first step in understanding coastal wellbeing. Such an understanding is a critical input for any sustainability and development agendas for 
coastal regions (e.g. Smith et al. 2006). Armitage et al. (2011) and Coulthard (2012) have already helped broaden the dialogue about coastal human wellbeing, agency, and the resilience of coastal socioecological systems and call for policies built on a deeper knowledge of coastal human wellbeing. Our results here can help continue to inform such a broader conceptualization of the wellbeing aspects of marine management as well as refine interventions in a way that is sensitive to multiple dimensions of poverty. Development approaches for improving these multiple dimensions might mean either synergies or tradeoffs with marine management for biodiversity (Jentoft et al. 2011, Fox et al. 2012a).

Table 1. Countries, year of survey, total number of clusters, and number of coastal clusters included in this analysis

\begin{tabular}{|c|c|c|c|}
\hline Country & $\begin{array}{c}\text { Survey } \\
\text { year }\end{array}$ & $\begin{array}{c}\text { No. } \\
\text { of } \\
\text { clusters }\end{array}$ & $\begin{array}{c}\text { No. of } \\
\text { coastal } \\
\text { clusters }\end{array}$ \\
\hline Albania & 2008 & 1616 & 340 \\
\hline Angola & 2011 & 8242 & 1981 \\
\hline Bangladesh & 2011 & 8753 & 1208 \\
\hline Bolivia & 2008 & 8605 & 0 \\
\hline Burkina Faso & 2010 & 15044 & 0 \\
\hline Burundi & 2010 & 7033 & 0 \\
\hline Cambodia & 2010 & 8003 & 569 \\
\hline Congo Democratic Republic & c 2007 & 8992 & 0 \\
\hline Cote d'Ivoire & 2012 & 7099 & 243 \\
\hline Egypt & 2008 & 10872 & 1888 \\
\hline Ethiopia & 2010 & 11654 & 0 \\
\hline Ghana & 2008 & 2992 & 481 \\
\hline Guinea & 2005 & 6364 & 802 \\
\hline Guyana & 2009 & 2178 & 1089 \\
\hline Haiti & 2006 & 3442 & 2781 \\
\hline Indonesia & 2002 & 9475 & 4848 \\
\hline Kenya & 2009 & 3328 & 212 \\
\hline Lesotho & 2009 & 3450 & 0 \\
\hline Liberia & 2011 & 3319 & 1128 \\
\hline Madagascar & 2008 & 2423 & 263 \\
\hline Malawi & 2010 & 19967 & 0 \\
\hline Mali & 2006 & 14238 & 0 \\
\hline Morocco & 2004 & 1690 & 679 \\
\hline Mozambique & 2011 & 11102 & 3019 \\
\hline Namibia & 2007 & 3734 & 117 \\
\hline Nepal & 2011 & 5306 & 0 \\
\hline Nigeria & 2008 & 28647 & 1468 \\
\hline Peru & 2000 & 13697 & 2475 \\
\hline Philippines & 2008 & 6572 & 4178 \\
\hline Rwanda & 2010 & 9002 & 0 \\
\hline Senegal & 2011 & 7660 & 710 \\
\hline Sierra Leone & 2008 & 5631 & 1309 \\
\hline Swaziland & 2006 & 4388 & 0 \\
\hline Tanzania & 2010 & 7304 & 1727 \\
\hline Timor-Leste & 2009 & 8140 & 4544 \\
\hline Uganda & 2011 & 7878 & 0 \\
\hline Zambia & 2007 & 6401 & 0 \\
\hline Zimbabwe & 2010 & 3015 & 0 \\
\hline
\end{tabular}

\section{METHODS}

Data

We used Demographic and Health Surveys (DHS) data (ICF International 2000-2012) from 38 countries across the years 2000 to 2012 (Table 1) for our analysis. DHS collect nationally and regionally representative survey data with large sample sizes. The sampling design is based on 2-stage clustering, first selecting enumeration clusters (villages or groups of villages) and then households within these clusters. Usually between 5000 and 30000 households per country are surveyed. The surveys themselves consist of comprehensive modules on subjects such as household health, education, wealth, and diet. Our subset of countries represents the surveys that have the full set of question modules as well as geospatial coordinates of community-cluster locations. As such, we are able to delineate where survey respondents live in relation to coastlines and therefore examine patterns in household health, wealth, and education between coastal and non-coastal communities and between urban and rural communities in these 38 countries (Table 1, Fig. 1). We defined coastal communities as those communities located within $20 \mathrm{~km}$ of the coast. The 'urban' and 'rural' designations used by DHS are based on the official statistics and census classifications of a given country. As such, rural and urban definitions vary across countries, and while possible inconsistencies do not affect any within-country comparisons, there is the possibility they might impact some results for which we aggregate across all 38 countries.

\section{Wellbeing indicators}

We selected 3 dimensions of wellbeing for our models and statistical tests. Our selections are analogous to the HDI's key areas of health, wealth, and education. We used childhood stunting for our health indicator, utilizing height-for-age standard deviations. Such standards set a level such that children more than 2 standard deviations below the mean of a 'healthy' reference group are considered stunted. Although the DHS has recently incorporated heightfor-age standard deviation variables calculated using the more recent child growth standards released by the World Health Organization (WHO 2006), these WHO measures were not available for all of the countries in our study. For this reason, we used the height-for-age standard deviations calculated accor- 


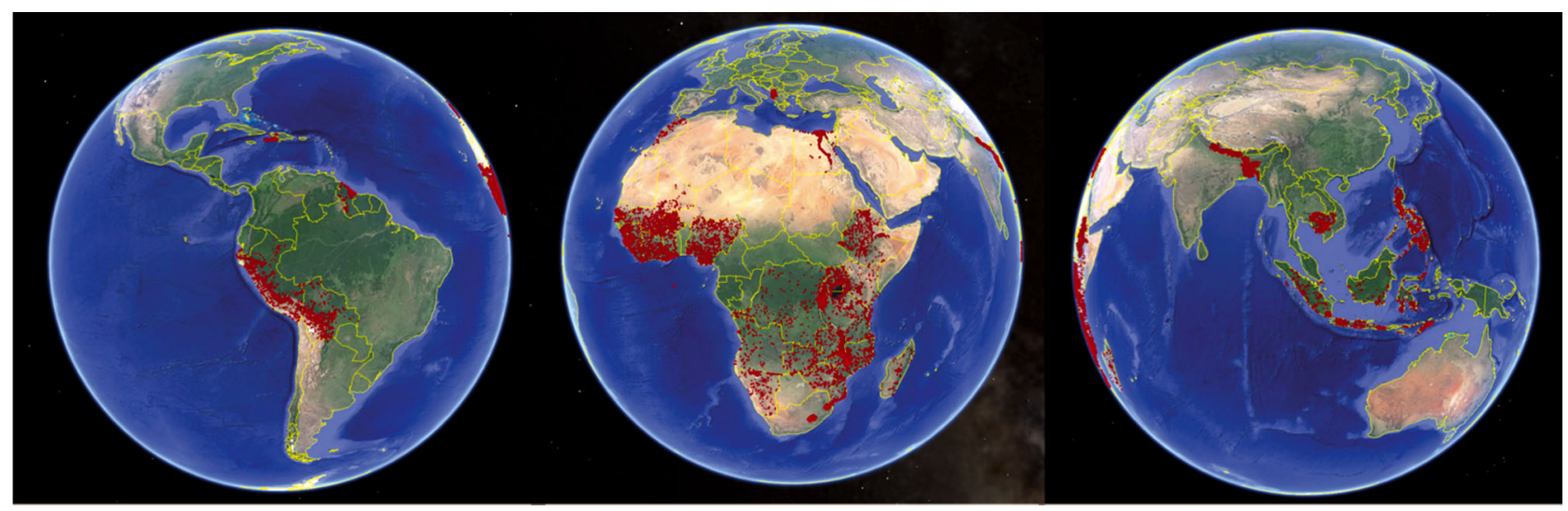

Fig. 1. Cluster locations (red) examined in this study

ding to standards set by the DHS, which were available for all of the surveys included here and are consistent across our dataset.

For wealth, we utilized the DHS country-specific numeric wealth index that categorizes wealth into 5 quintiles, from poorest to richest. The wealth index itself is a composite measure of a household's cumulative living standard (based on a comprehensive asset assessment and a principle components analysis) for that given country and thus is comparable across households within a given country but not directly comparable across countries (Rutstein \& Johnson 2004).

For our third wellbeing metric, we used the highest level of education attained (standardized across countries) for the adult responding to the survey questions and living in the same household as the children analyzed in this study. In most but not all cases, the survey respondent was the mother or caregiver of the child measured.

\section{Modeling}

We first asked if stunting, wealth, and educational status differed between coastal and non-coastal communities and between urban and rural communities within coastal areas. We asked if there was an interaction effect between coast/non-coast and urban/rural on the response variables across all countries. We performed linear mixed model regressions in R ( $\mathrm{R}$ Development Core Team 2008) using the lme4 package (Bates et al. 2014) and conducted separate regressions for each of the 3 response variables (childhood stunting, household wealth, education of the respondent). We used the linear mixed effects model function (lmer) for stunting, since it was a continuous numerical value.
Because our education and wealth metrics were categorical variables, we used the generalized linear mixed effects model function (glmer). However, because the glmer function does not include a distribution family for ordered categorical variables, we created new binary response variables for wealth and education. For wealth, we combined the 'poorest' and 'poorer' categories into one 'poor' category and all other categories (middle, richer, richest) into a 'not poor' category. For education, we combined 'no education' and 'primary' categories into a 'low' education category and the rest (secondary, higher) into a 'high' education category. We compared the fit of models using all possible combinations of the fixed effects (i.e. urban versus rural, coastal versus non-coastal, and their interaction) using Akaike's Information Criterion (AIC). All models included the random effect of cluster within country. We did not include the random effect of household within cluster (within country) because the majority of households only had a single child for which height and weight were measured. After finding the model with the best fit (i.e. lowest AIC score), we estimated the significance of the fixed effects in the model using the likelihood ratio test (e.g. fit the full model including a particular fixed effect, fit it again without that term, calculate the difference in the deviance values, and compare that to a chi-square distribution). If the best fit model contained the interaction term, we only estimated the significance of the interaction term. To explore exactly how stunting, educational attainment, and wealth differed among coastal/noncoastal and urban/rural coastal communities, we calculated the mean and standard error of the height-for-age standard deviations, the proportion of households that had low educational attainment, and the proportion of households identified as poor. 
Table 2. Linear mixed model results. Category in parentheses for fixed effects is used for interpreting the parameter estimate for the variable. Estimated p-value was obtained by likelihood ratio test for the interaction variable only (see 'Methods')

\begin{tabular}{|c|c|c|c|c|c|c|c|c|}
\hline \multirow[t]{2}{*}{ Response variable } & \multicolumn{4}{|c|}{ Fixed effects included in best fit model -} & \multicolumn{3}{|c|}{ Random effects } & \multirow[t]{2}{*}{ AIC } \\
\hline & Variable & Estimate & $\begin{array}{c}\text { SE of } \\
\text { estimate }\end{array}$ & $\begin{array}{l}\text { Estimated } \\
\text { p-value }\end{array}$ & Group & Variance & SE & \\
\hline \multirow{3}{*}{$\begin{array}{l}\text { Height for age } \\
\text { standard deviations }\end{array}$} & Urban/Rural (Urban) & 0.452 & 0.014 & - & Country & 0.089 & 0.299 & \multirow[t]{3}{*}{610269.8} \\
\hline & Coastal/Non-Coastal (Coastal) & 0.278 & 0.052 & - & Cluster & 0.221 & 0.47 & \\
\hline & Interaction & -0.105 & 0.036 & 0.004 & Household & 2.299 & 1.516 & \\
\hline \multirow[t]{3}{*}{ Poor versus not poor } & Urban/Rural (Urban) & -4.647 & 0.054 & - & Country & 0.759 & 0.871 & \multirow[t]{3}{*}{253002.5} \\
\hline & Coastal/Non-Coastal (Coastal) & -1.113 & 0.079 & - & Cluster & 4.235 & 2.058 & \\
\hline & Interaction & 0.693 & 0.108 & $<0.0001$ & & & & \\
\hline \multirow{3}{*}{$\begin{array}{l}\text { Low education versus } \\
\text { high education }\end{array}$} & Urban/Rural (Urban) & -2.174 & 0.03 & - & Country & 2.266 & 1.505 & \multirow[t]{3}{*}{228142.3} \\
\hline & Coastal/Non-Coastal (Coastal) & -0.712 & 0.054 & - & Cluster & 1.839 & 1.356 & \\
\hline & Interaction & 0.261 & 0.067 & 0.0002 & & & & \\
\hline
\end{tabular}

\section{RESULTS}

\section{Coastal versus non-coastal communities}

Results from the linear mixed model analyses showed significant differences in health, wealth, and educational attainment between coastal and noncoastal as well as between urban and rural communities (Table 2). We also found substantial variation among countries and among clusters within countries. For all 3 response variables (height-for-age standard deviations for children, household wealth, and educational attainment of the respondent), the best fit models included coastal/non-coastal and urban/rural variables and their interaction (Table 2). The sign of the coefficients show that being urban and coastal was associated with improved health, wealth, and educational outcomes, with 'urban' as the factor that had the strongest effect. Although likelihood ratio tests suggested significant interactions between coastal/non-coastal and urban/rural communities for all response variables $(\mathrm{p}<0.05$ for all interactions), the greatest differences in stunting, wealth, and educational attainment were between urban and rural communities regardless of whether they were coastal or not (Fig. 2). When we just look at the differences between rural and urban households (regardless of their relation to the coast), rural communities had 1.5 times lower height-for-age standard deviation scores, were 4 times more likely to be poor, and were 1.6 times more likely to have poor education than urban households.

Coastal communities had higher levels of wellbeing than non-coastal communities (when controlling for rural/urban) across all indicators. Coastal children were less stunted, marginally less poor, and more likely to live in a more educated household (Table 2, Fig. 2).
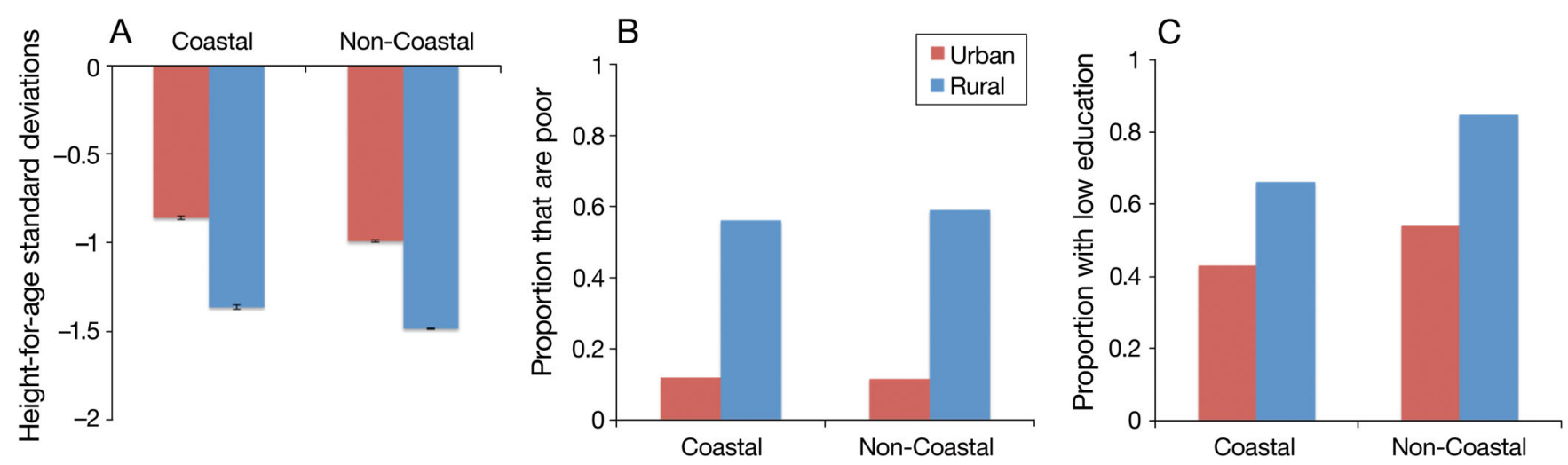

Fig. 2. (A) Mean height-for-age standard deviations from reference population (a measure of stunting) $\pm 1 \mathrm{SE}$, (B) proportion of households that were poor, and $(\mathrm{C})$ proportion of respondents that had low educational attainment (no education or primary) across urban/rural and coastal/non-coastal communities pooled across 38 countries 


\section{Across coastal communities}

We found analogous differences in health, wealth, and educational attainment between urban and rural communities when we look just at coastal communities. In general, rural coastal communities were more stunted, poorer, and had lower levels of education when compared with urban coastal communities (Fig. 3). However, the magnitude of these differences varied substantially across countries (Fig. 3). For example, in most countries, childhood stunting rates were significantly higher for rural coastal communities when compared to urban coastal communities. However, in Bangladesh, Kenya, and Madagascar, differences between rural and urban coastal communities were not significant. For these countries, the average height-for-age standard deviations for both rural and urban coastal communities were between -1.1 and -1.7 . Thus, these countries may be outliers because low height-for-age scores are so widely prevalent. For example, in Bangladesh, the average child verges on being stunted (average $=-1.65$ ), and more than $40 \%$ of the under- 5 children are officially considered stunted (height-for-age scores less than -2.0), whereas in coastal communities in Morocco, the average child's height-for-age is -0.41 standard deviations below the reference population.

Across all countries, the proportion of coastal households that were poor in rural areas was much higher than that in urban areas, and in 13 of 24 countries, rural coastal poverty represented the majority of households. In Cote d'Ivoire, Indonesia, Liberia, and the Philippines, over $70 \%$ of rural coastal households were considered poor. In terms of educational status of households, differences between rural and urban were less obvious than with asset poverty. In 13 of 24 countries, at least $50 \%$ of coastal households had low levels of education, regardless of whether they were urban or rural. There was also variation across countries with regard to education; some countries show large urban-rural disparities (e.g. Peru, Nigeria), while in others (e.g. Senegal, Namibia), the differences are quite small. Across all countries, rural coastal households were 1.5 times more likely to have poor educational status when compared to urban coastal communities.

\section{DISCUSSION}

Here, we took a first step toward gaining a better understanding of the multiple dimensions of poverty along coastlines in developing countries. Broadly, our results indicate a staggering level of deprivation across the developing countries in our dataset, including high levels of childhood stunting, pervasive asset poverty, and low educational status of households. However, while fishery, or at least rural coastal communities may still 'rhyme with poverty' in many parts of the world, the coastal communities in our dataset fared better, on average, than non-coastal communities regarding childhood stunting, wealth, and educational status (Fig. 2). One potential explanation for this is the low cost barrier to fishing that may deliver improved wellbeing outcomes than other, especially non-coastal rural, occupations (Daw et al. 2012). The low cost barrier means that fishing can also provide supplementary household sustenance and income to reduce poverty when fishing is not the primary occupation and serve as a 'safety-net' against transient poverty and shocks (Béné 2006, Béné et al. 2009). Another explanation might be the higher connectivity of coastal communities to trading and exchange markets (e.g. major ports), which may or may not interact with the availability of fish $-\mathrm{a}$ highly tradable commodity and source of nutrition itself.

However, despite the small improvements in our wellbeing metrics for coastal communities, it remains that coastal communities across developing countries suffer high levels of childhood malnutrition (as indicated by our stunting data), high levels of poverty, and low levels of education. This is especially so for rural coastal communities. Here, we cannot identify the mechanisms leading to these large urban-rural disparities specifically on the coast; however, urbanrural disparities in health and socioeconomics have been explored by others (e.g. Smith et al. 2005, Fotso 2007, Van de Poel et al. 2007). Recognizing these disparities within coastal communities should help guide near-term targeting for development and conservation interventions, especially where coastal livelihoods are highly dependent on marine resources and those resources are under threat of decline. For exploratory purposes, we tested fish protein consumption data from FAO and plotted it against our poverty and stunting metrics aggregated to the country level. We found no significant relationship between per capita fish consumption and poverty or childhood stunting at the national level $(\mathrm{r}=-0.026$, $\mathrm{p}=0.909$ and $\mathrm{r}=0.106, \mathrm{p}=0.666$, respectively).

Understanding the causal relationships between coastal natural resources (e.g. near shore fish stocks, estuary health, reef health) and our poverty metrics is a major limitation of this paper. The ideal models would attempt to predict changes in our wellbeing 


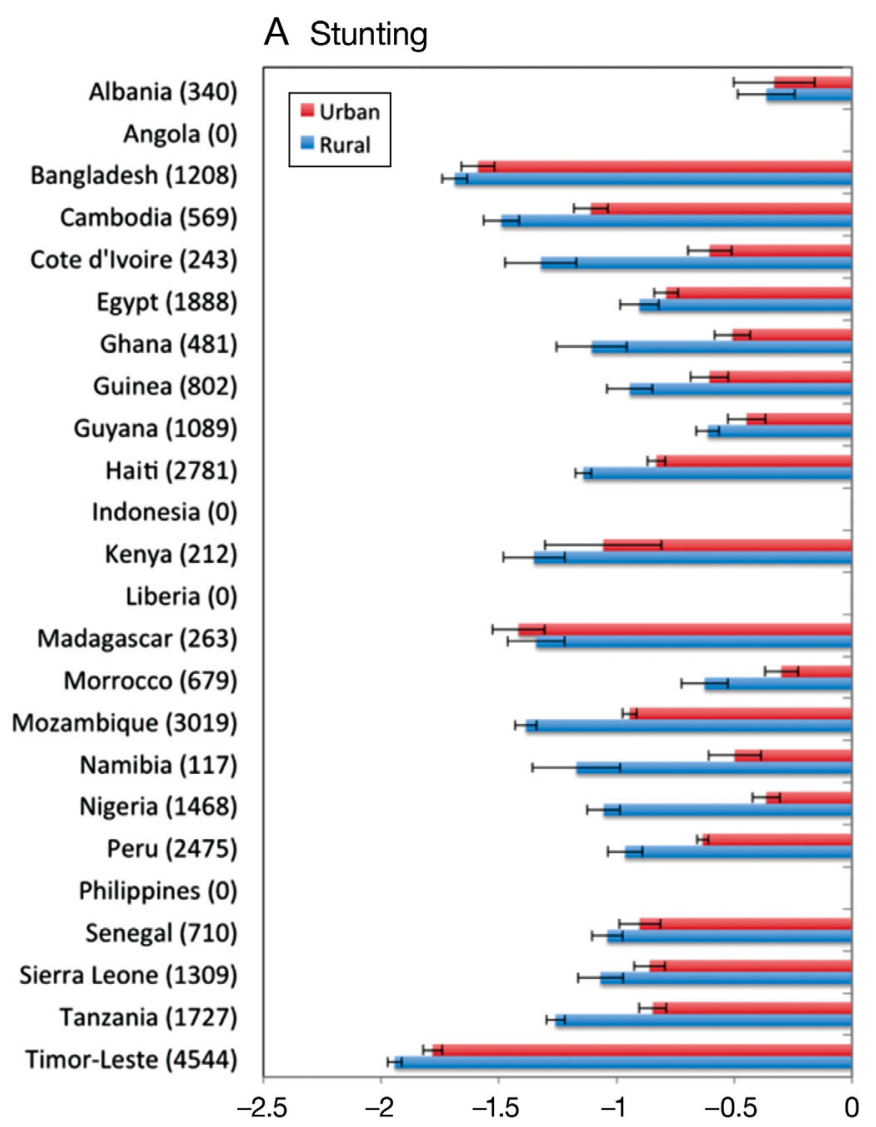

C Proportion with low education

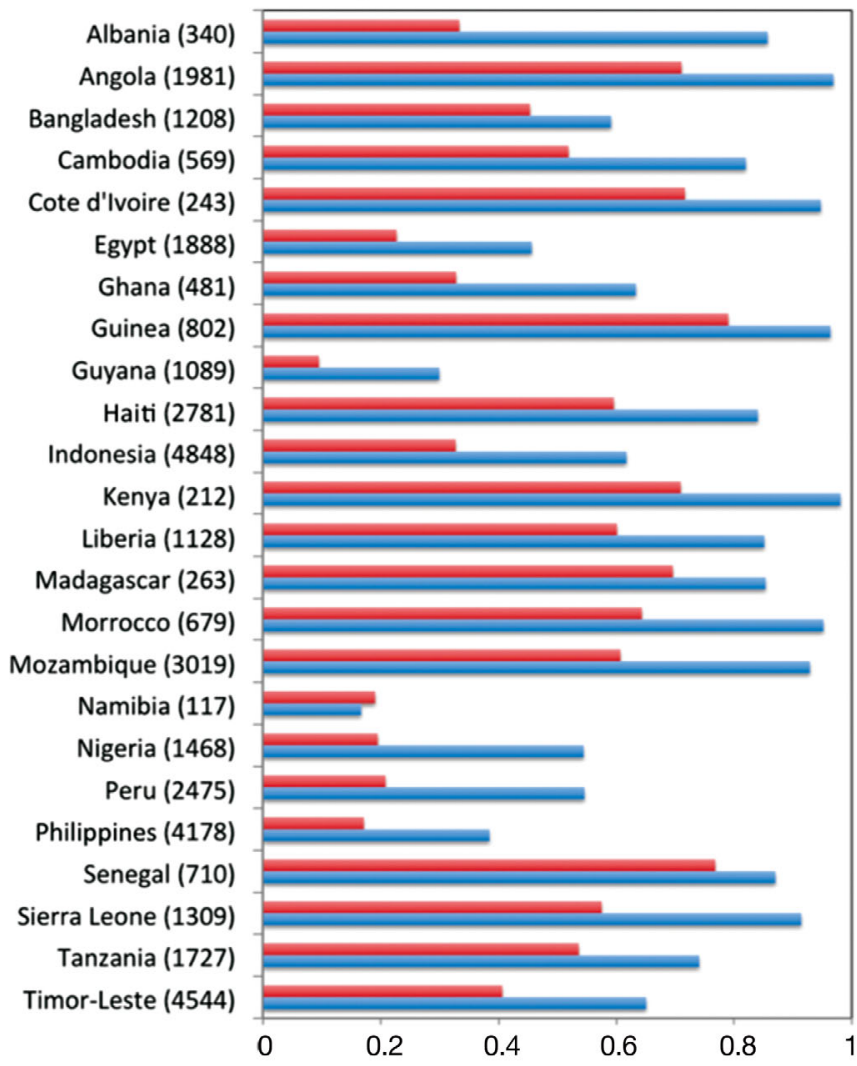

B Proportion that are poor

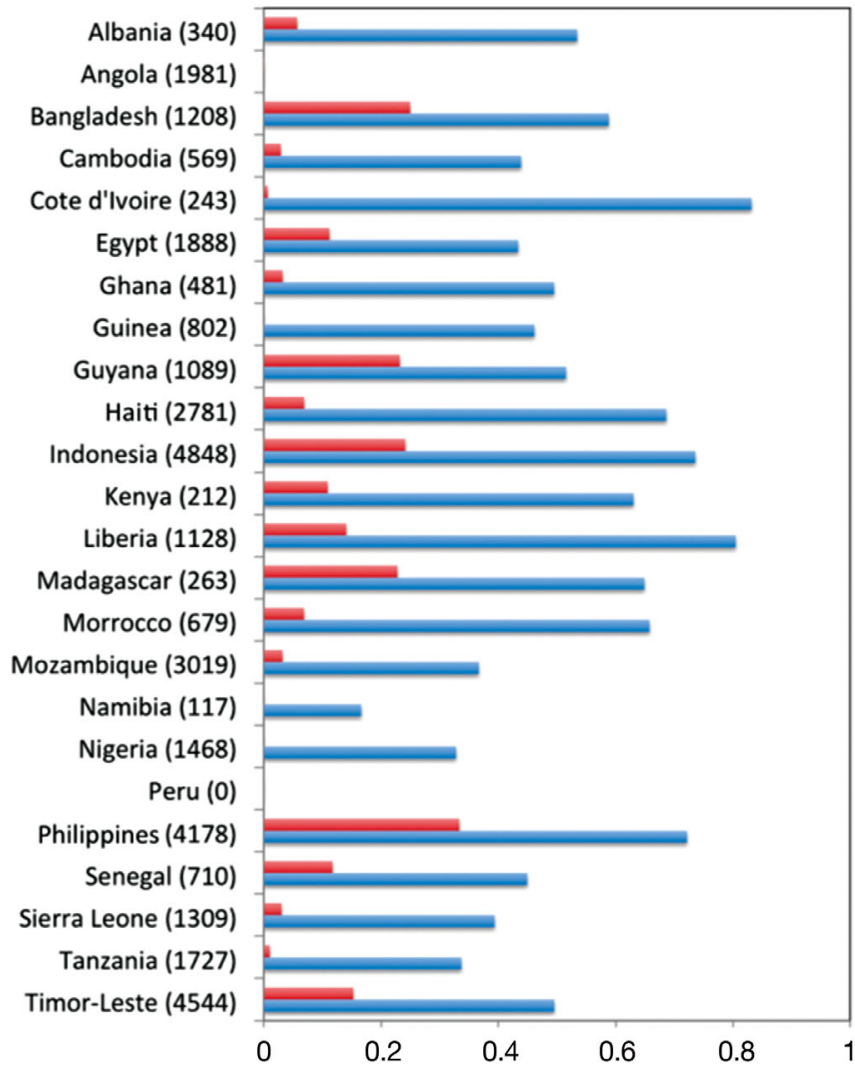

Fig. 3. (A) Stunting (mean height-for-age standard deviations from reference population) $\pm 1 \mathrm{SE}$, (B) proportion of households that were poor, and (C) proportion of survey respondents with low educational attainment for coastal communities in each country. Numbers in parentheses for each country and response variable indicate total sample size 
metrics (across space or time) as a function of changes in marine ecological conditions. Currently, we do not have datasets that easily lend themselves for analysis of this type. For example, we attempted to use a global dataset of human impact on oceans (Halpern et al. 2008) as a dependent variable in a model to predict our wellbeing metrics. However, there was little to no variation in impact scores along the coasts for some countries, whereas for the same countries, our dataset contained hundreds of village clusters. In other cases, we had the opposite problem, where for a given cluster, there was a wide range of impact scores one could choose from (given a $10 \mathrm{~km}$ buffer along the coast). In these cases, we were left with the decision to arbitrarily pick a score or average them (weighted by scale, impact, or area). Regardless of our approach, we were making assumptions and ignoring the mobile aspect of fishing activities and pushing a dataset to a level of resolution that it was not designed to handle (Halpern et al. 2008). Integrating 2 such datasets is clearly an important next step for this type of research.

Despite the lack of causal attribution between our wellbeing data and coastal ecological conditions, the results here can help inform coastal marine management and hence help underpin a wider economic cost-benefit evaluation of coastal management decisions. Perry et al. (2011) showed that fishing communities respond to shocks and change by diversifying their livelihood approaches and increasing their fishing effort in the short term. The potential that fishing communities have to diversify on both land and water might be one reason that coastal communities in our dataset have higher levels of wellbeing across our metrics when compared to non-coastal communities. However, multiple livelihood strategies are only effective if the resources on which they are based are in good condition. Understanding where households that are poor in health, wealth, and educational status are along coasts can help inform policies and interventions aimed at managing coastal ecosystems but do so where there is a potential to buffer or improve coastal livelihoods.

As such, there are existing approaches attempting to simultaneously meet conservation and development goals (Rosenberg \& McLeod 2005). Rights-based and co-management approaches can help deliver improved fish biomass (e.g. Cinner et al. 2012) and improve livelihood benefits (e.g. Brooks et al. 2012); notake zones and marine protected areas (MPAs) can help maintain the ecological functions that support coastal fish stocks (Leisher et al. 2007); and capacity building and leadership programs in coastal manage- ment can help deliver the longer term human capital needed to improve the resiliency of coastal livelihoods (Gutierrez et al. 2011). When partnered with health or other development programs, the outcomes of both conservation and development programs can indeed be improved (D'Agnes et al. 2010).

However, there is a real need, especially within national policy discussions, to better understand the wider social and economic benefits (and tradeoffs) of marine management (Mascia et al. 2010). Many developing countries around the world, including many of those in our data set, have 2 primary policy objectives. One is food security, and the other is economic growth. Given that some 3 billion people, many of them in the developing world, depend on fish protein as a critical source of protein in their diet (Allison 2011), the link between fisheries management and food security is not a big stretch. However, rural coastal livelihoods, such as small-scale fishing, tend to lend small contributions to national gross domestic product, except for some small island developing countries, but can play an extremely important role in local food security and livelihoods (Béné 2006). If national policies and international programs can focus equally on national and local food security and economic growth, then perhaps over time we will see some improvements in human wellbeing along coasts.

Our results here suggest that the spatial scale of policies and their targeting will clearly affect their effectiveness for improving human wellbeing. Policies and interventions that rely on existing infrastructure and address industrial fisheries might not impact those who are most deprived: rural communities. However, programs and policies that aim to improve the wellbeing of the poorest and most vulnerable communities should probably invest in strategies that are particularly sensitive to rural conditions. Our results suggest that field programs that work with rural coastal communities, such as establishing or managing coastal MPAs and sustainable artisan fisheries, have the largest potential to impact human wellbeing. If we are to understand the wider socioeconomic benefits (and tradeoffs) of marine conservation and management, these field programs need to systematically monitor human wellbeing as well as ecological indicators (Mascia et al. 2010, Fox et al. 2012a). Given that investments in human capital and improvements in human health are important drivers of human wellbeing and economic growth (Anand \& Sen 2000, Barro 2001), a policy or program focus that seeks to sustain marine resources might do well to incorporate education and health interventions (Gjertsen 2005, D'Agnes et al. 2010). 
Understanding the wider social and more longterm economic benefits derived from well-functioning coastal systems requires an understanding of the wellbeing of those most likely to bear the costs of continued declines in health of coastal systems and those who could reap the benefits of more sustainable and restored coastal systems. Our results could be a starting point for this wider understanding and perhaps point to the need for differentiated policies and programs for urban and rural coastal communities given the different levels of human capital and human health across several dozens of developing countries.

Acknowledgements. This work was supported by a grant from the Rockefeller Foundation's Ocean and Fisheries Initiative 2013 OCE 202. This work benefited from support from National Socio-Environmental Synthesis Center (SESYNC)National Science Foundation award DBI-1052875. B.F. was additionally supported by a Bellagio Center Residency granted by the Rockefeller Foundation.

\section{LITERATURE CITED}

Allison EH (2011) Aquaculture, fisheries, poverty and food security. Working Paper 2011-65, WorldFish Center, Penang

Allison EH, Perry AL, Badjeck MC, Adger WN and others (2009) Vulnerability of national economies to the impacts of climate change on fisheries. Fish Fish 10:173-196

Anand S, Sen A (2000) Human development and economic sustainability. World Dev 28:2029-2049

Armitage D, Bene C, Charles AT, Johnson D, Allison EH (2011) The interplay of well-being and resilience in applying a social-ecological perspective. Ecol Soc 17:15

- Barro RJ (2001) Human capital and growth. Am Econ Rev 91:12-17

Bates D, Maechler M, Bolker B, Walker S (2014) lme4: linear mixed-effects models using Eigen and S4. R package version 1.0-6. http://CRAN.R-project.org/package=lme4

Béné C (2003) When fishery rhymes with poverty: a first step beyond the old paradigm on poverty in small-scale fisheries. World Dev 31:949-975

Béné C (2006) Small-scale fisheries: assessing their contribution to rural livelihoods in developing countries. FAO, Rome

Béné C, Steel E, Luadia BK, Gordon A (2009) Fish as the 'bank in the water' - evidence from chronic-poor communities in Congo. Food Policy 34:108-118

- Brooks JS, Waylen KA, Mulder MB (2012) How national context, project design, and local community characteristics influence success in community-based conservation projects. Proc Natl Acad Sci USA 109:21265-21270

Cinner JE, McClanahan TR, MacNeil MA, Graham NAJ and others (2012) Comanagement of coral reef social-ecological systems. Proc Natl Acad Sci USA 109:5219-5222

Coulthard S (2012) Can we be both resilient and well, and what choices do people have? Incorporating agency into the resilience debate from a fisheries perspective. Ecol Soc $17: 4$
D'Agnes L, D'Agnes H, Schwartz JB, Amarillo ML, Castro J (2010) Integrated management of coastal resources and human health yields added value: a comparative study in Palawan (Philippines). Environ Conserv 37:398-409

> Daw TM, Cinner JE, McClanahan TR, Brown K, Stead SM, Graham NAJ, Maina J (2012) To fish or not to fish: factors at multiple scales affecting artisanal fishers' readiness to exit a declining fishery. PLoS ONE 7:e31460

FAO (Food and Agriculture Organization of the United Nations) (2012) State of the world's fisheries and aquaculture. FAO, Rome

Fotso JC (2007) Urban-rural differentials in child malnutrition: trends and socioeconomic correlates in sub-Saharan Africa. Health Place 13:205-223

> Fox HE, Mascia MB, Basurto X, Costa A and others (2012a) Reexamining the science of marine protected areas: linking knowledge to action. Conserv Lett 5:1-10

> Fox HE, Soltanoff CS, Mascia MB, Haisfield KM, Lombana AV, Pyke CR, Wood L (2012b) Explaining global patterns and trends in marine protected area (MPA) development. Mar Policy 36:1131-1138

> Gjertsen H (2005) Can habitat protection lead to improvements in human well-being? Evidence from marine protected areas in the Philippines. World Dev 33: $199-217$

Gutierrez NL, Hilborn R, Defeo O (2011) Leadership, social capital and incentives promote successful fisheries. Nature 470:386-389

Halpern BS, Walbridge S, Selkoe KA, Kappel CV and others (2008) A global map of human impact on marine ecosystems. Science 319:948-952

> Halpern BS, Longo C, Hardy D, McLeod KL and others (2012) An index to assess the health and benefits of the global ocean. Nature 488:615

> Hughes S, Yau A, Max L, Petrovic N and others (2012) A framework to assess national level vulnerability from the perspective of food security: the case of coral reef fisheries. Environ Sci Policy 23:95-108

Hughes TP, Baird AH, Bellwood DR, Card M and others (2003) Climate change, human impacts, and the resilience of coral reefs. Science 301:929-933

ICF International (2000-2012) Demographic and health surveys (various) [Datasets]. Calverton, MD, http://dhs program.com/data/ (accessed 22 Feb 2014)

> Jalan J, Ravallion M (1999) Are the poor less well insured? Evidence on vulnerability to income risk in rural China. J Dev Econ 58:61-81

> Jentoft S, Chuenpagdee R (2009) Fisheries and coastal governance as a wicked problem. Mar Policy 33:553-560

> Jentoft S, Chuenpagdee R, Pascual-Fernandez JJ (2011) What are MPAs for: on goal formation and displacement. Ocean Coast Manage 54:75-83

Kittinger J (2013) Human dimensions of small-scale and traditional fisheries in the Asia-Pacific region. Pac Sci 67 : 315-325

Leisher C, Van Beukering P, Scherl L (2007) Nature's investment bank: how marine protected areas contribute to poverty reduction. The Nature Conservancy, Arlington, VA

Marschke MJ, Berkes F (2006) Exploring strategies that build livelihood resilience: a case from Cambodia. Ecol Soc 11:42

Mascia MB, Claus CA, Naidoo R (2010) Impacts of marine protected areas on fishing communities. Conserv Biol 24: 1424-1429 
Perry RI, Ommer RE, Barange M, Jentoft S, Neis B, Sumaila UR (2011) Marine social-ecological responses to environmental change and the impacts of globalization. Fish Fish 12:427-450

R Development Core Team (2008) R: a language and environment for statistical computing. R Foundation for Statistical Computing, Vienna

Ravallion M (2001) Growth, inequality and poverty: looking beyond averages. World Dev 29:1803-1815

Ravallion M, Chen S, Sangraula P (2007) New evidence on the urbanization of global poverty. The World Bank, Washington, DC

Rosenberg A, McLeod K (2005) Implementing ecosystembased approaches to management for the conservation of ecosystem services. Mar Ecol Prog Ser 300:270-274

Rutstein SO, Johnson K (2004) The DHS wealth index. DHS Comparative Reports No 6. ORC Macro, Calverton, MD

Sagar AD, Najam A (1998) The human development index: a critical review. Ecol Econ 25:249-264

Satterthwaite D (2002) The ten and a half myths that may distort the urban policies of governments and international agencies. IIED G03188. International Institute for Environment and Development, London

Schaafsma M, Morse-Jones S, Posen P, Swetnam RD and others (2014) The importance of local forest benefits: eco-

Submitted: March 25, 2014; Accepted: February 6, 2015 nomic valuation of non-timber forest products in the eastern Arc Mountains in Tanzania. Global Environ Change 24:295-305

Sen A (1985) Commodities and capabilities. North-Holland, Amsterdam

Smith LC, Ruel MT, Ndiaye A (2005) Why is child malnutrition lower in urban than in rural areas? Evidence from 36 developing countries. World Dev 33:1285-1305

Smith MD, Roheim CA, Crowder LB, Halpern BS and others (2010) Sustainability and global seafood. Science 327: 784-786

Smith TF, Alcock D, Thomsen DC, Chuenpagdee R (2006) Improving the quality of life in coastal areas and future directions for the Asia-Pacific region. Coast Manag 34:235-250

Teh LCL, Sumaila UR (2013) Contribution of marine fisheries to worldwide employment. Fish Fish 14:77-88

UNDP (United Nations Development Programme) (1990) Human Development Report 1990. Oxford University Press, Oxford

Van de Poel E, O'Donnell O, Van Doorslaer E (2007) Are urban children really healthier? Evidence from 47 developing countries. Soc Sci Med 65:1986-2003

WHO (World Health Organization) (2006) WHO child growth standards. WHO, Geneva

Proofs received from author(s): March 20, 2015 